\title{
Infusion of Platelet-derived Growth Factor or Basic Fibroblast Growth Factor Induces Selective Glomerular Mesangial Cell Proliferation and Matrix Accumulation in Rats
}

\author{
Jürgen Floege, Eudora Eng, ${ }^{\ddagger}$ Bessie A. Young, ${ }^{*}$ Charles E. Alpers, * Thomas B. Barrett, * \\ Daniel F. Bowen-Pope, * and Richard J. Johnson* \\ Division of Nephrology, Medizinische Hochschule, Hannover 61, Germany; and ${ }^{\ddagger}$ Division of Nephrology, Department of Medicine, and \\ * Department of Pathology, University of Washington, Seattle, Washington 98195
}

\begin{abstract}
Mesangial cell (MC) proliferation and extracellular matrix expansion are involved in the pathogenesis of glomerulosclerosis and renal failure. In vitro, PDGF and basic fibroblast growth factor (bFGF) regulate MC proliferation and/or matrix production. To elucidate the role of PDGF and bFGF in vivo, equimolar concentrations of recombinant PDGF-BB or bFGF or vehicle were infused intravenously into rats over a 7-d period. Rats were either nonmanipulated ("normals") or had received a subnephritogenic dose of anti-MC antibody ("anti-Thy 1.1 rats") before the infusion period. Glomerular cell proliferation (anti-proliferating cell nuclear antigen immunostaining) on days 2,4 , and 7 was unchanged in vehicle-infused normals or anti-Thy 1.1 rats. PDGF infusion increased glomerular cell proliferation 32-fold in anti-Thy 1.1 rats and an 11-fold in normals on day 2. bFGF increased glomerular cell proliferation fourfold in anti-Thy 1.1 rats but was ineffective in normals. Induction of cell proliferation in all kidneys was limited to the glomerulus. The majority of proliferating cells were identified as MC by double immunolabeling. No significant proteinuria, glomerular leukocyte, or platelet influx developed in any group. Glomerular matrix expansion with increased deposition of type IV collagen, laminin, and fibronectin, as well as upregulated laminin and collagen IV mRNA expression was confined to PDGF-infused anti-Thy 1.1 rats. These results show that PDGF and, to a lesser degree, bFGF are selective $M C$ mitogens in vivo and that previous subclinical injury can enhance this MC response. The data thereby support a role of these cytokines in the pathogenesis of glomerulosclerosis. (J. Clin. Invest. 1993.92:2952-2962.) Key words: glomerulonephritis • glomerulosclerosis • collagen • fibronectin • laminin
\end{abstract}

\section{Introduction}

Proliferation of intrinsic glomerular mesangial cells as well as expansion of the mesangial extracellular matrix are central features of numerous experimental and human glomerular diseases (1-3). Both processes are thought to play an important

Address correspondence and reprint requests to R. J. Johnson, M.D., Division of Nephrology RM-11, University of Washington, Seattle, WA 98195.

Received for publication 20 May 1993 and in revised form $26 \mathrm{Au}$ gust 1993.

J. Clin. Invest.

(C) The American Society for Clinical Investigation, Inc. $0021-9738 / 93 / 12 / 2952 / 11 \$ 2.00$

Volume 92, December 1993, 2952-2962 role in the development of glomerular sclerosis and renal failure $(1,3)$. Over the last five years, evidence has accumulated to link cytokines to the regulation of mesangial cell proliferation and matrix synthesis (reviewed in references 1 and 4). However, most of this evidence is correlative and a causal role of cytokines has been difficult to demonstrate.

We (5), as well as others (6), have recently outlined criteria to establish a role for a cytokine in mediating a specific biological effect in glomerular disease. These criteria include $(a)$ the demonstration that the cytokine has the effect on target cells in vitro; $(b)$ the demonstration that the cytokine is released or expressed in diseases and correlates with the proposed effect; (c) the demonstration that inhibition of the cytokine in vivo blocks the postulated effect of the cytokine in disease; and $(d)$ the demonstration that administration of the cytokine in vivo (or overexpression in transgenic animals) reproduces the biological effect.

In the case of two cytokines, PDGF and basic fibroblast growth factor (bFGF), ${ }^{1}$ a number of these criteria have been fulfilled and have linked them to mesangial cell proliferation and mesangial matrix accumulation: (a) Both PDGF (mainly the $\mathrm{BB}$ isoform) and bFGF exhibit potent mitogenic effects on cultured mesangial cells (7-10). PDGF has also been shown to be involved in the regulation of their matrix synthesis (11). (b) Numerous reports have shown that glomerular PDGF synthesis and PDGF receptor expression are increased in both experimental and human mesangial proliferative diseases (reviewed in references 5 and 6 ). Recently, we have also presented evidence that glomerular bFGF release and synthesis are increased in the rat mesangial proliferative anti-Thy 1.1 nephritis model (10). (c) Inhibition of PDGF with a neutralizing antibody led to significant reduction of both mesangial cell proliferation and matrix accumulation in the anti-Thy 1.1 model (12).

In the present study, we have attempted to fulfill the fourth criterion, namely to show that the exogenous administration of PDGF or bFGF can induce biological effects in vivo. Previously, limited data of ours had shown that a single bolus injection of bFGF into rats that had received a previous subnephritogenic mesangial insult could induce low grade mesangial cell proliferation (10). Subnephritogenic injury was defined as the maximal dose of anti-mesangial cell antibody (anti-Thy 1.1/ antithymocyte serum) that could be administered without inducing significant morphological changes in the glomeruli. In the present study, we have expanded on this observation and

1. Abbreviations used in this paper: ATS, antithymocyte serum; bFGF, basic fibroblast growth factor; PAS, periodic acid-Schiff; PCNA, proliferating cell nuclear antigen; PDGF, platelet-derived growth factor. 
have analyzed the effects of a 1-wk infusion of recombinant PDGF-BB and/or bFGF on glomerular cell proliferation and matrix accumulation. To evaluate the influence of the mesangial cell status on the cytokine responsiveness, we have investigated the effects of infusion of PDGF-BB and/or bFGF into both normal rats, as well as into rats that had previously received a subnephritogenic dose of antithymocyte serum (ATS). The results show that administration of PDGF-BB to normal rats and especially to rats injected with subnephritogenic doses of ATS can induce pronounced histological changes in the glomerulus, namely increased mesangial cell proliferation and mesangial matrix accumulation, resembling those observed in mesangial proliferative glomerulonephritis. On a molar basis, PDGF-BB was considerably more potent than bFGF. bFGF led to only mild mesangial cell proliferation in subnephritogenic ATS rats and did not induce significant changes in normal rats. The data thereby provide further evidence for a causal role of bFGF and, in particular, PDGF in the mediation of mesangial cell proliferation and matrix expansion in vivo.

\section{Methods}

Experimental design. To evaluate the renal effects of PDGF and bFGF, 15 normal male Wistar rats (Simonson, Gilroy, CA) weighing $180-220 \mathrm{~g}$ received a 7-d intravenous infusion of either PDGF-BB $(n$ $=4)$, $\operatorname{bFGF}(n=3), \operatorname{PDGF}-\mathrm{BB}$ plus $\operatorname{bFGF}(n=3)$, or vehicle $(n=5)$. In addition, we studied $26 \mathrm{Wistar}$ rats that had received a single intravenous injection of a subnephritogenic dose of goat anti-rat thymocyte serum at $30 \mathrm{~min}$ after the start of the infusion period (subnephritogenic ATS rats) (infusion of PDGF-BB: $n=9$; bFGF: $n=6$; PDGF-BB plus bFGF: $n=5$; vehicle: $n=6)$. The subnephritogenic dose of ATS $(0.1$ $\mathrm{ml} / 100 \mathrm{~g}$ body wt as opposed to the regularly used dose of $0.5 \mathrm{ml} / 100 \mathrm{~g}$ [13]) was chosen as the maximum amount of ATS that could be administered without inducing an increase in the glomerular cell proliferation rate. Cytokines or vehicle, respectively, were continuously infused through a catheter in the left internal jugular vein with microosmotic pumps ( filling volume $=200 \mu \mathrm{l}$; delivery rate $=1 \mu \mathrm{l} / \mathrm{h}$ ) (Alzet Corp., Palo Alto, CA ). 24-h urinary protein excretion was determined on days $1-2,3-4$, and 6-7 after the implantation of the pumps. Renal biopsies, as well as blood samples, for urea nitrogen and creatinine were obtained from each rat on days 2 and 4 and upon death (day 7).

In each kidney biopsy, we evaluated the total glomerular cell number and the number of proliferating glomerular or tubulointerstitial cells (as defined by immunostaining for the proliferating cell nuclear antigen [PCNA] [13]). Mesangial cell proliferation and activation were analyzed directly by double immunostaining for PCNA and the Thy 1.1 antigen on the mesangial cell surface (14), as well as by immunostaining for the glomerular de novo expression of $\alpha$-smooth muscle actin (15). To exclude that increases in glomerular or tubulointerstitial cellularity and cell proliferation rate resulted from infiltrating leukocytes, the numbers of monocytes/macrophages, neutrophils, and lymphocytes were also evaluated using specific monoclonal antibodies. Furthermore, immunostaining was performed to detect glomerular expression of growth factors (PDGF and bFGF), their receptors (PDGF receptor $\beta$ subunit), and to assess glomerular extracellular matrix expansion as reflected by immunostaining for type I and IV collagen, laminin, and fibronectin. To assess the intrinsic synthesis rate of PDGF and laminin, in situ hybridization for PDGF B chain mRNA and Northern analysis of total glomerular RNA for the expression of laminin $B_{2}$ chain mRNA was performed.

Additional experiments were designed to evaluate the mechanism(s) underlying the increased potency of PDGF-BB in rats injected with subnephritogenic ATS. To investigate whether upregulation of growth factor receptor expression might be involved, total glomerular
RNA was isolated from six normal Wistar rats and six rats $48 \mathrm{~h}$ after the injection of subnephritogenic ATS. Northern and dot blots were then probed with a cDNA specific for PDGF receptor $\beta$ subunit mRNA. Furthermore, we investigated whether the intravenous injection of subnephritogenic ATS led to an increase of the glomerular procoagulant activity, as assessed by immunostaining for platelets and fibrinogen, which might enhance mesangial cell proliferation. Finally, experiments were performed to exclude the possibility that the injected ATS led to release of mediators from thymocytes that might act synergistically with the infused PDGF. For this reason, nine rats received a subnephritogenic ATS dose $(50 \mu \mathrm{l})$ via infusion into the left renal artery $(16)$ with concomitant drainage of the left renal vein, thereby preventing systemic effects of the infused ATS. Subsequently PDGF-BB or vehicle was infused for $48 \mathrm{~h}$. After death, glomerular cell proliferation was then assessed separately in the left and right kidneys.

$P D G F$ and $b F G F$ infusion. The $\mathrm{BB}$ homodimer of recombinant human PDGF (mol mass $=28 \mathrm{kD}$ ) was a kind gift from C. Hart $(\mathrm{Zy}-$ mogenetics, Seattle, WA). Human recombinant bFGF (molecular mass $=18 \mathrm{kD}$ ) was kindly provided by $\mathrm{R}$. Eure (Synergen, Boulder, $\mathrm{CO}$ ). The amounts of cytokines infused were chosen in a way that equimolar amounts were administered (40 $\mu \mathrm{g}$ PDGF-BB/d and $25 \mu \mathrm{g}$ $\mathrm{bFGF} / \mathrm{d}$ ). Both cytokines were dissolved in $10 \mathrm{mM}$ PBS, pH 7.4. As shown in Table I, PDGF-BB and, to a lesser degree, bFGF maintain their biological activity in this buffer if incubated at $37^{\circ} \mathrm{C}$ for $\leq 1 \mathrm{wk}$. Completeness of delivery of the cytokines in vivo was controlled by examining the pumps at the end of the experiments.

Renal morphology. Tissue for light microscopy and immunoperoxidase staining was fixed in methyl Carnoy's solution (13) and embedded in paraffin. 4- $\mu \mathrm{m}$ sections were stained with the periodic acidSchiff (PAS) reagent and counterstained with hematoxylin. In the PAS-stained sections the total number of nuclei per glomerular cross section was counted. For each biopsy, $>20$ cross sections ( range $=20$ 50 ) of consecutive cortical glomeruli containing $>20$ discrete capillary segments each were evaluated by one of the authors, who was unaware of the origin of the slides. Mesangiolysis was graded semiquantitatively on a scale from 0 to $4+$, as previously described (15). Glomerular matrix expansion was assessed by staining sections with silver methenamine.

Immunoperoxidase staining. 4- $\mu \mathrm{m}$ sections of methyl Carnoy's fixed biopsy tissue were processed by a direct or indirect immunoperoxidase technique as previously described (13). Primary antibodies

Table I. Biological Activity of Recombinant Human PDGF-BB or bFGF

\begin{tabular}{llcc}
\hline \multicolumn{1}{c}{ Stimulus } & \multicolumn{1}{c}{$\begin{array}{c}\text { Incubation } \\
\text { time }\end{array}$} & $\begin{array}{c}\text { Incorporated } \\
{\left[{ }^{3} \mathrm{H}\right] \text { thymidine }}\end{array}$ & $\begin{array}{c}\text { Relative potency } \\
\text { (percent of freshly } \\
\text { thawed) }\end{array}$ \\
\hline None & & $c p m$ & \\
PDGF-BB & & $5,300 \pm 900$ & - \\
$(20 \mathrm{ng} / \mathrm{ml})$ & Freshly thawed & $73,600 \pm 3,400$ & 100 \\
& 2 d at $37^{\circ} \mathrm{C}$ & $91,200 \pm 7,300$ & 123 \\
& 4 d at $37^{\circ} \mathrm{C}$ & $85,000 \pm 1,400$ & 115 \\
& 7 d at $37^{\circ} \mathrm{C}$ & $92,350 \pm 4,100$ & 124 \\
bFGF (30 ng/ml) & Freshly thawed & $69,000 \pm 8,000$ & 100 \\
& 2 d at $37^{\circ} \mathrm{C}$ & $80,000 \pm 3,000$ & 116 \\
& 4 d at $37^{\circ} \mathrm{C}$ & $64,000 \pm 8,000$ & 93 \\
& 7 d at $37^{\circ} \mathrm{C}$ & $44,000 \pm 5,000$ & 64 \\
\hline
\end{tabular}

Data are mean \pm SD of four experiments each. Both cytokines were incubated in $10 \mathrm{mM}$ PBS, $\mathrm{pH} 7.4$, for various lengths of time. Bioactivity was then determined by measuring $\left[{ }^{3} \mathrm{H}\right]$ thymidine incorporation rates in serum-starved $3 \mathrm{~T} 3$ fibroblasts stimulated for $24 \mathrm{~h}$ with these cytokines as described (9). 
included 19A2 (Coulter Corp., Hialeah, FL), a murine IgM monoclonal antibody against human PCNA, which is expressed by actively proliferating cells (17); a murine monoclonal antibody to an $\mathrm{NH}_{2}$-terminal synthetic decapeptide of $\alpha$-smooth muscle actin (kind gift of G. Gabbiani, University of Geneva, Geneva, Switzerland)(18); ED1 (Bioproducts for Science, Indianapolis, IN), a murine monoclonal IgG to a cytoplasmic antigen present in monocytes, macrophages, and dendritic cells (19); RP-3 (kind gift of F. Sendo, Yamagata University, Yamagata, Japan), a murine monoclonal IgM antibody to rat neutrophils (20); OX-22 (Accurate Chemical Corp., Westbury, NY), a murine monoclonal antibody to the high molecular weight form of the rat common leukocyte antigen expressed on B lymphocytes and most $\mathrm{T}$ lymphocytes; PGF-007 (a kind gift of Mochida Pharmaceutical, Tokyo, Japan) a murine monoclonal IgG antibody to a 25-amino acid peptide located near the $\mathrm{COOH}$ terminus of the human PDGF B chain (21); a rabbit polyclonal antibody to the $\beta$ subunit of the PDGF-receptor as described elsewhere (22) (kindly provided by R. Seifert, University of Washington, Seattle, WA); DE6, a murine monoclonal $\mathrm{IgG}_{1}$ antibody against rh-bFGF (kindly provided by $T$. Reilly, Du PontMerck, Wilmington, DE) (23); an IgG fraction of polyclonal rabbit anti rat laminin (Chemicon, Temecula, CA); an IgG fraction of polyclonal guinea pig anti rat type I collagen (24) kindly provided by L. Iruela-Arispe, University of Washington, Seattle, WA); a biotinylated (25) IgG fraction of polyclonal goat anti mouse type IV collagen (Southern Biotech, Birmingham, AL); an affinity purified IgG fraction of a polyclonal rabbit anti-rat fibronectin (Chemicon); a polyclonal goat anti-rat fibrinogen antibody (Cappel Laboratories, Cochranville, PA); and PL-1, a murine monoclonal antibody against rat platelets (kind gift from W. W. Bakker, University of Groningen, Groningen, The Netherlands) (26).

For all biopsies, negative controls consisted of substitution of the primary antibody with equivalent concentrations of an irrelevant murine monoclonal antibody or normal rabbit IgG.

Mean values per biopsy were calculated for the number of proliferating (PCNA+) cells and leukocytes per glomerular cross section (see comment above). To obtain mean numbers of proliferating cells and infiltrating leukocytes in the cortical tubulointerstitium, 30 grid fields measuring $0.1 \mathrm{~mm}^{2}$ each were evaluated. For the evaluation of the immunoperoxidase stains for $\alpha$-smooth muscle actin, PDGF B-chain, PDGF receptor $\beta$ subunit, bFGF and the various matrix proteins, each glomerulus was graded semiquantitatively as described previously (27), and the mean score per biopsy was calculated. Each score reflects mainly changes in the extent rather than intensity of mesangial staining. 0: diffuse, very, weak or absent mesangial staining. No localized increases of staining. 1+: Diffuse, weak mesangial staining with $\leq 25 \%$ of the glomerular tuft showing focally increased staining. $2+: 25-50 \%$ of the glomerular tuft demonstrating a focal, strong staining. 3+: 50$75 \%$ of the glomerular tuft stained strongly in a focal manner. 4+: $>75 \%$ of the glomerular tuft stained strongly.

Immunohistochemical double staining. Double immunostaining for the identification of the type of proliferating cells was performed as reported previously (28) by first staining the sections for proliferating cells with 19A2, an IgM monoclonal antibody to PCNA, followed by staining with the $\mathrm{IgG}_{1}$ monoclonal antibody OX-7 (Accurate Chemical Corp.), an antibody against the Thy 1.1 antigen present on the mesangial cell membrane. Cells were identified as proliferating mesangial cells if they showed positive nuclear staining for PCNA and if the nucleus was completely surrounded by cytoplasm or cell membrane positive for OX-7. Proliferating cells in which the PCNA-positive nucleus did not border on the cytoplasm or cell membrane positive for OX-7 were classified as nonmesangial. Proliferating (PCNA+) cells that could not be clearly identified as $\mathrm{OX}-7$ positive or negative were considered nonclassifiable.

In situ hybridization for PDGF B chain. In situ hybridization was performed on $4-\mu \mathrm{m}$ sections of biopsy tissue fixed in buffered $10 \%$ formalin using a digoxigenin-labeled antisense cRNA probe for the murine PDGF B chain (derived from a cDNA kindly provided by Charles Stiles, Harvard University, Boston, MA) as described (29). Detection of the cRNA probe was performed with an alkaline phospha- tase coupled antidigoxigenin antibody (Genius Nonradioactive Nucleic Acid Detection Kit; Boehringer-Mannheim GmbH, Mannheim, Germany) with subsequent color development. Controls consisted of hybridization with a sense probe to matched serial sections, by hybridization of the antisense probe to tissue sections that had been incubated with RNAse A before hybridization, or by deletion of the probe, antibody, or color solution (29).

Preparation of glomerular RNA and Northern analysis. Glomeruli were isolated by differential sieving (15). Total RNA was extracted from glomeruli either as described (PDGF receptor) (30) or with RNAzol B a ater the manufacturer's instructions (Cinna/Biotecx Laboratories, Friendswood, TX) (laminin $B_{2}$ chain). The latter RNA obtained was further purified by a $\mathrm{LiCl}$ precipitation as described elsewhere (28). For Northern analysis, the RNA was denatured and 15 $\mu \mathrm{g} /$ lane were electrophoresed through a formaldehyde/agarose gel and transferred to a nylon filter (Hybond N®; Amersham Corp., Arlington Heights, IL) as described (15). The cDNA probes used for Northern analysis were as follows: ( $a$ ) PDGF receptor $\beta$ subunit: A 5.1-kb EcoRI fragment of mouse PDGF receptor $\beta$ subunit cDNA from plasmid pIBI (31) was used to detect the 5.7-kb rat PDGF receptor $\beta$ subunit transcript. (b) Laminin $\mathrm{B}_{2}$ chain: A 1.7-kb EcoRi/Xbal fragment of mouse laminin $B_{2}$ cDNA isolated from plasmid p1298 was used to detect the $8-\mathrm{kb}$ laminin $\mathrm{B}_{2}$ transcript (32). The probe was a kind gift of $Y$. Yamada (National Institutes of Health, Bethesda, MD). (c) Type IV collagen: A 1.8-kb EcoRi/Hind III fragment of mouse $\alpha 1$ (IV) collagen cDNA from plasmid pPE123 was used for the detection of the 6.2- and 6.8-kb type IV collagen transcripts. The probe was a kind gift of $\mathrm{M}$. Kurkinen (Robert Wood Johnson Medical School, Piscataway, NJ). (d) 28S ribosomal RNA: A bovine 280-bp cDNA probe was used to detect $28 \mathrm{~S}$ ribosomal RNA (kindly provided by Dr. Luisa Iruela-Arispe and Dr. Helene Sage, University of Washington, Seattle, WA) (33).

All probes were labeled with $\left[\alpha-{ }^{32} \mathrm{P}\right]$ deoxycytidine 5-triphosphate (3,000 Ci/mmol, New England Nuclear, Boston, MA) by random primer extension. Positive controls included total RNA isolated from murine BALB/c 3T3 fibroblasts (PDGF receptor $\beta$ subunit) and glomeruli at $5 \mathrm{~d}$ after the induction of anti-Thy 1.1 glomerulonephritis in rats (laminin $B_{2}$ chain).

To quantitate the amount of mRNA for each sample, membranes were prehybridized and hybridized as described (15) and autoradiograms were obtained and signal intensity was determined by PhophorImager (10i) analysis (Molecular Dynamics, Sunnyvale, CA) (15). Total RNA in each sample was then determined by reprobing with a cDNA specific for $28 \mathrm{~S}$ ribosomal RNA. All Northern analyses were repeated two to three times with glomerular RNA preparations obtained from different sets of animals. Alternatively, dot blots were prepared as described (28) and analyzed using the same procedure as described above.

Miscellaneous measurements. Urinary protein was measured by a method using sulfosalicylic acid (34) with a whole serum standard (Lab Trol; Dade Diagnostics, Aquado, Puerto Rico). Urea nitrogen and creatinine were measured in serum using an autoanalyzer (Beckman Instruments, Brea, CA).

Statistical analysis. All values are expressed as mean \pm SD. Statistical significance (defined as $P<0.05$ ) was evaluated using the Student's $t$ test or one-way ANOVA with modified $t$ tests performed using the Bonferroni correction (35).

\section{Results}

PDGF-BB infusion selectively induces glomerular hyperplasia in normal rats. PAS staining of renal biopsies obtained from normal rats infused with PDGF-BB ( $28 \mathrm{ng} / \mathrm{min}$ ) or equimolar concentrations of PDGF-BB ( $28 \mathrm{ng} / \mathrm{min}$ ) and bFGF (17 ng/ min ) revealed mild glomerular hypercellularity with increased total cell counts (Fig. 1), while no changes were noted in the tubulointerstitium and vessels. Renal biopsies of rats infused with bFGF ( $17 \mathrm{ng} / \mathrm{min}$ ) or vehicle had a normal appearance and normal glomerular cell counts (Fig. 1). No additive or 


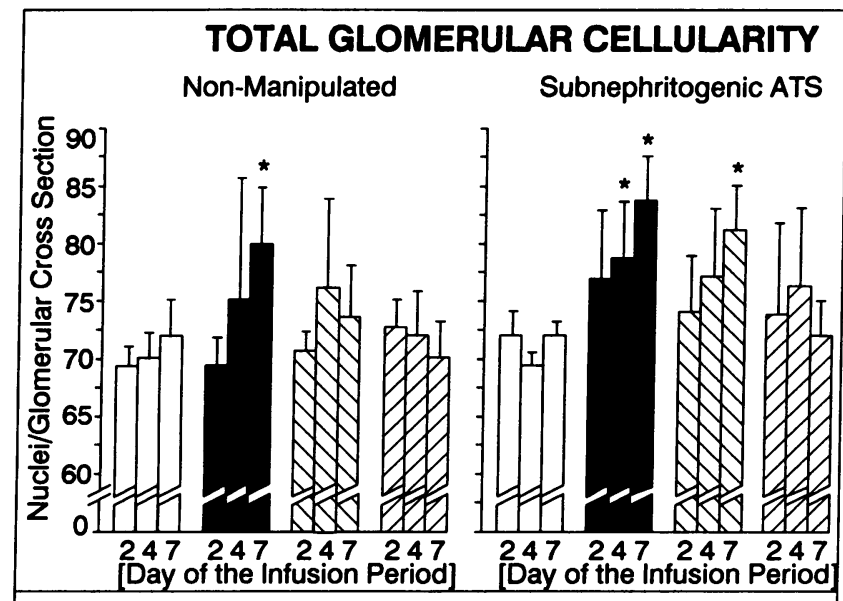

PROLIFERATING GLOMERULAR CELLS

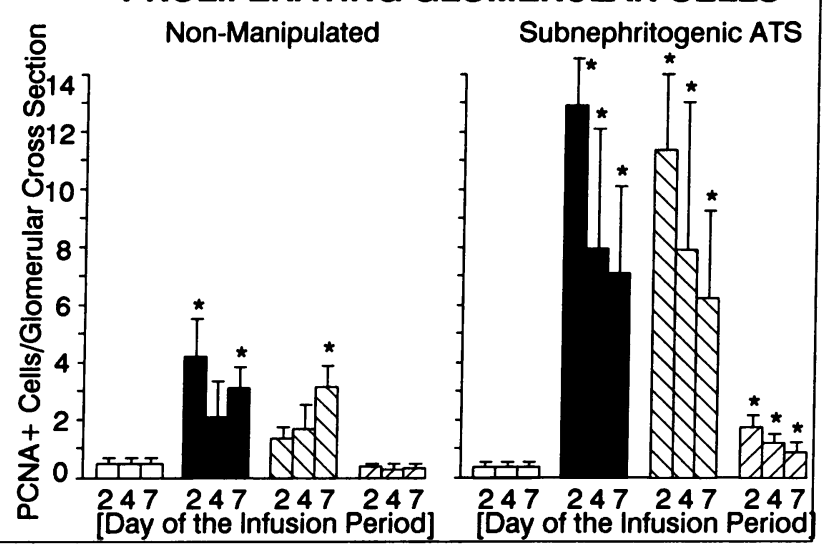

$$
\mathrm{n}=(5) \quad \text { (4) (3) (3) (6) (9) }
$$

Figure 1. Total glomerular cellularity and cell proliferation: glomerular total cell counts and proliferating cells (as defined by immunostaining for PCNA) per glomerular cross-section in normal and subnephritogenic ATS rats receiving a 1-wk infusion of either PDGF-BB (匹), PDGF-BB plus bFGF (ब), bFGF (田), or vehicle (ם). ${ }^{*} P<0.05$ vs corresponding vehicle-infused group.

synergistic effect between PDGF-BB and bFGF was observed (Fig. 1). The number of proliferating glomerular cells increased up to eightfold in PDGF-BB infused rats, but not in bFGF-infused rats (Fig. 1). Again, no further increase was observed when PDGF-BB and bFGF were combined (Fig. 1).

Fig. 2 shows that the induction of cell proliferation in the kidneys of PDGF-BB-infused rats was confined to glomeruli, while no change was observed in the cortical tubulointerstitium (counts of proliferating cells in tubulointerstitial fields ranged from $1.1 \pm 0.4$ to $1.5 \pm 0.9 \mathrm{PCNA}+$ cells $/ 0.1 \mathrm{~mm}^{2}$ at any of the time points examined). Furthermore, neither PDGF-BB nor bFGF infusion led to an apparent increase in smooth muscle cell proliferation in larger vessels within the kidney.

Mitogenicity of PDGF-BB and bFGF in vivo depends on the cellular status. To evaluate the effect of a minimal mesangial cell insult at the start of PDGF-BB and/or bFGF infusion, rats received a subnephritogenic dose of ATS. Fig. 1 confirms that this ATS dose was subnephritogenic, since it did not induce significant cell proliferation within the glomeruli of vehicle-infused rats. PAS-stained tissue sections obtained from these latter rats revealed rare mild mesangiolysis, which was, however, not sufficient to result in a significant increase of the mesangio- lysis index. No other morphological abnormalities, increased glomerular influx of macrophages and platelets, or deposition of fibrin was noted in the subnephritogenic ATS rats (data not shown).

Fig. 1 shows that in subnephritogenic ATS rats, total glomerular cellularity increased significantly during the infusion of PDGF-BB. This increase was higher than that observed in PDGF-BB-infused normal rats, although the difference between subnephritogenic ATS rats and normals was not statistically significant. bFGF infusion led to a significant increase of the total glomerular cellularity after $4 \mathrm{~d}$ in subnephritogenic ATS rats but not in normal rats (Fig. 1). No synergism between the two cytokines was noted (Fig. 1). Counting of proliferating cells in the glomerulus revealed $a \leq 32$-fold increase in PDGF-BB-infused subnephritogenic ATS rats and an $\leq 4.5$ fold increase in bFGF infused rats (Fig. 1). The changes observed were significantly higher than those observed in the corresponding normal rats $(P<0.05$ subnephritogenic ATS rats vs normal rats) at all time points. Proliferating cell counts in glomeruli of subnephritogenic ATS rats infused with PDGFBB plus bFGF were comparable to those receiving PDGF-BB alone (Fig. 1).

As in the normal rats, the PDGF-BB- or bFGF-induced cell proliferation in the kidneys of subnephritogenic ATS rats was confined to the glomerulus (Fig. 2), and no significant alterations were observed in the cortical tubulointerstitium or in large vessels.

In both normal and subnephritogenic ATS rats, the increases in glomerular PCNA-positive cells were associated with an increased frequency of mitoses in the glomeruli. In subnephritogenic ATS rats receiving PDGF-BB, occasional glomeruli contained more than one cell in mitosis (Fig. 3 ). This was never observed in normal rats.

Increased glomerular cellularity is mainlycaused by mesangial cell proliferation. The increase in glomerular cellularity and cell proliferation was not caused by an infiltration of (proliferating) monocytes/macrophages, neutrophils, or lymphocytes, since these cell counts in glomeruli and tubulointerstitium remained normal in all groups (data not shown). Double immunostaining for PCNA and Thy 1.1 in PDGF-BB-infused normal or subnephritogenic ATS rats revealed that the majority of proliferating glomerular cells were mesangial cells (Fig. 4 ). In contrast, in vehicle-infused rats, the majority of proliferating glomerular cells were nonmesangial, presumably endothelial cells (36). Similar to the cell proliferation induced by PDGF-BB, bFGF infusion also induced proliferation of mainly mesangial cells in subnephritogenic ATS rats (Fig. 4). No PCNA-positive nuclei were observed in locations corresponding to podocytes in any of the groups. Despite the induction of marked mesangial cell proliferation, no de novo expression of $\alpha$-smooth muscle actin in glomeruli was noted in response to any treatment (data not shown).

Effects of PDGF-BB and bFGF infusion on the expression of intrinsic mesangial cell growth factors. Normal immunostaining patterns in the kidney for PDGF B chain, PDGF receptor $\beta$ subunit, and bFGF, using the same antibodies as used in the present study, have been reported previously $(10,22)$ and were not different in this study. Furthermore, the results of in situ hybridization for PDGF B-chain mRNA in glomeruli of normal rats were comparable to those reported previously (29).

Neither PDGF nor bFGF infusion led to a significant increase of the glomerular immunostaining score for PDGF B chain (normal score $=0.8 \pm 0.2$ ) in any of the groups. The fail- 

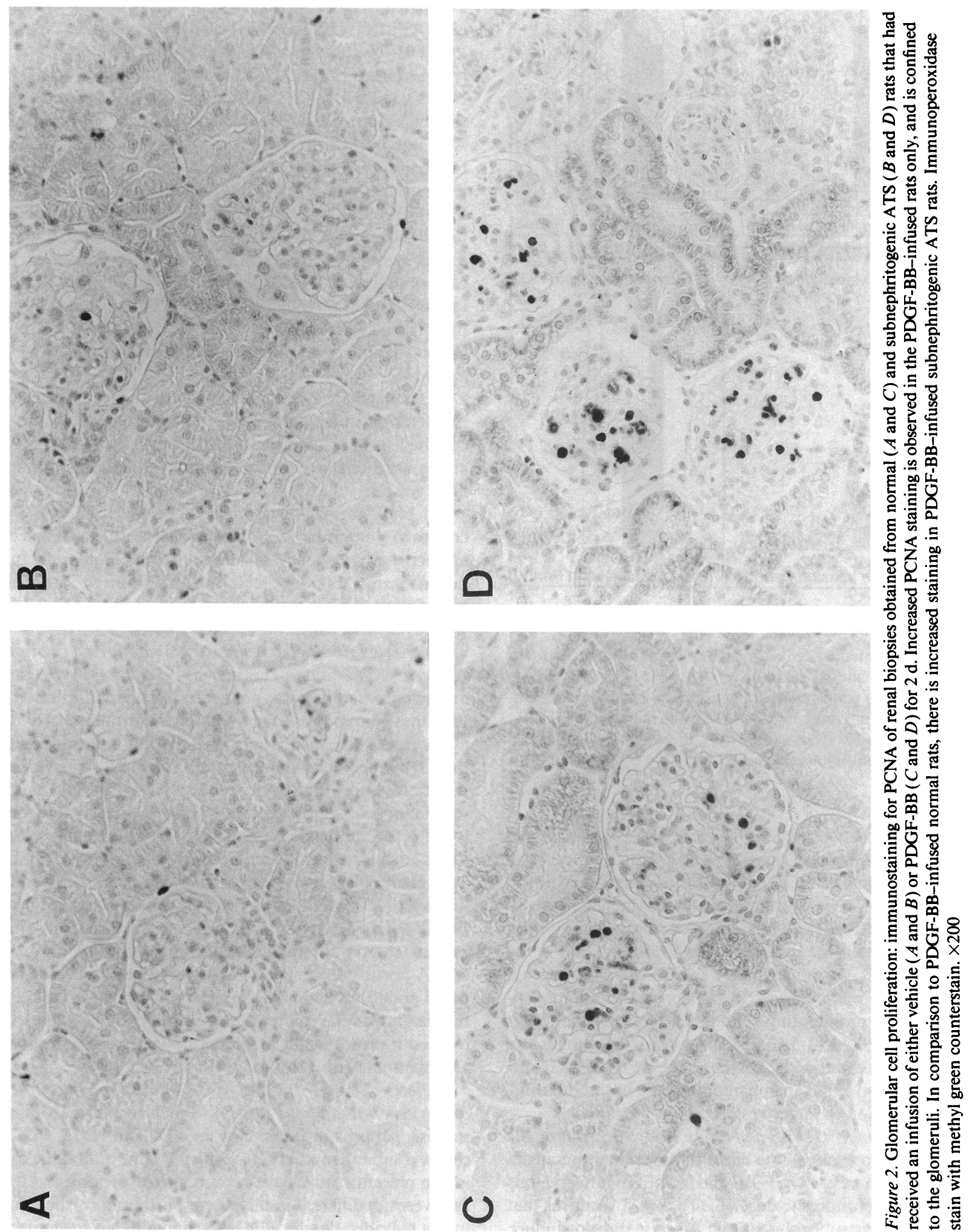


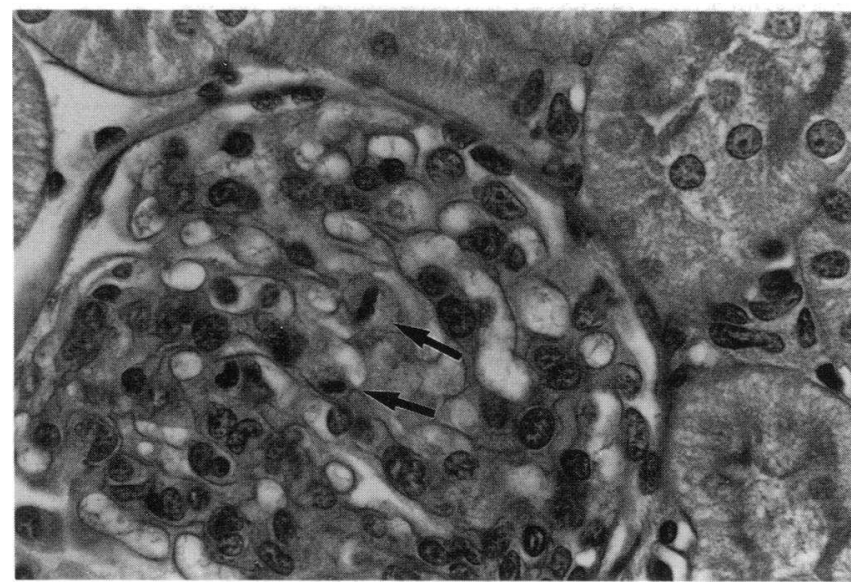

Figure 3. Glomerular mitoses: PAS stain of a renal biopsy of a PDGF-BB-infused subnephritogenic ATS rat on day 2 after the start of the infusion period. In the glomerular tuft, two cells in mitosis are observed (arrows). $\times 1,000$.

ure of exogenously administered PDGF-BB or bFGF to induce glomerular PDGF synthesis was also supported by the results of in situ hybridization for PDGF B chain mRNA, which, like the immunostaining, failed to reveal any change from the control pattern in any of the experimental groups (data not shown ). In contrast to PDGF B chain, the glomerular immuno-

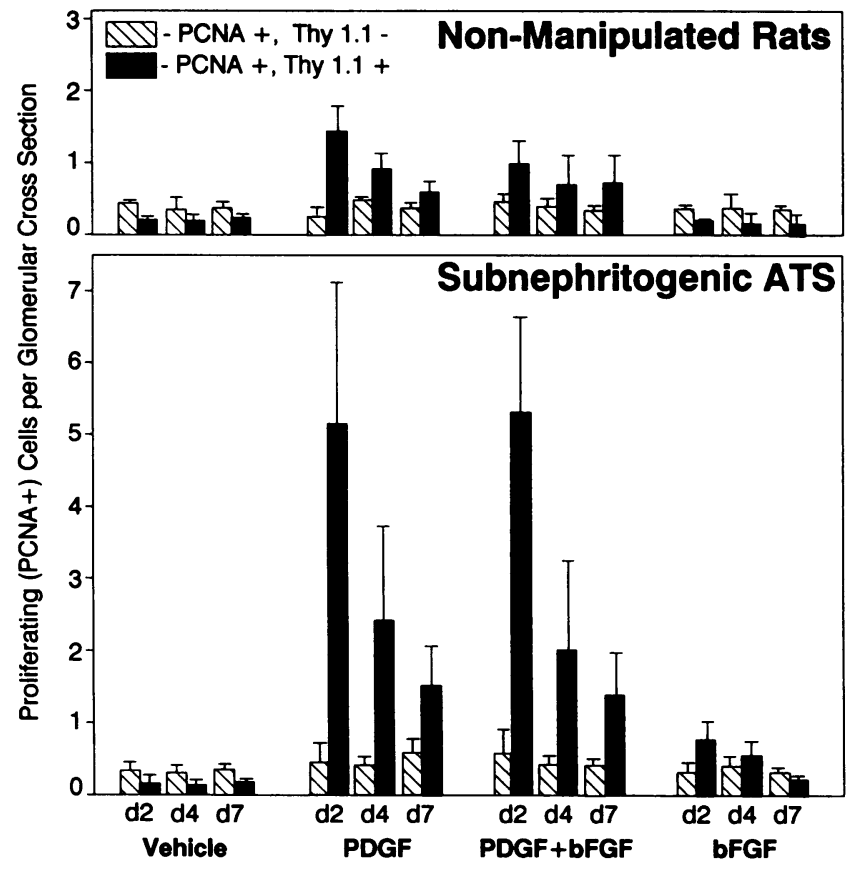

Figure 4. Identification of proliferating glomerular cells: double immunostaining for PCNA and the Thy 1.1 antigen expressed on mesangial cell surfaces. Data are presented as counts of proliferating glomerular cells per glomerular cross section that were either double labeled (i.e., proliferating mesangial cells) or not double labeled (i.e., proliferating nonmesangial cells). It is apparent that the counts of proliferating mesangial cells increase in the PDGF-BB-infused groups, as well as in bFGF-infused subnephritogenic ATS rats. Because of the different histochemical technique (see Methods), PCNA counts differ from those presented in Fig. 1. staining scores for both PDGF receptor $\beta$ subunit and bFGF increased in those groups where significant cell proliferation was present (Fig. 5).

Neither PDGF nor bFGF infusion led to significant glomerular deposition of platelets or to thrombus formation (data not shown), both of which contain various mesangial cell mitogens $(1,4)$.

Increased responsiveness of subnephritogenic ATS rats to $P D G F$ is associated with a mild upregulation of PDGF receptor. The injection of a subnephritogenic dose of ATS led to a small increase in the levels of glomerular PDGF receptor $\beta$ subunit mRNA on day 2 after the injection (Table II). As shown in Fig. 5, there was also a small increase in the glomerular staining score for PDGF receptor $\beta$ subunit after the administration of subnephritogenic ATS. In contrast, as noted above, no significant glomerular deposition of platelets or fibrinogen was observed in these latter rats.

Fig. 6 shows that the renal responsiveness to PDGF-BB was still increased if a subnephritogenic dose of ATS was administered selectively into one kidney rather than systemically. In this case the response in the left kidney, which received the ATS, was significantly higher than in the right nonperfused kidney.

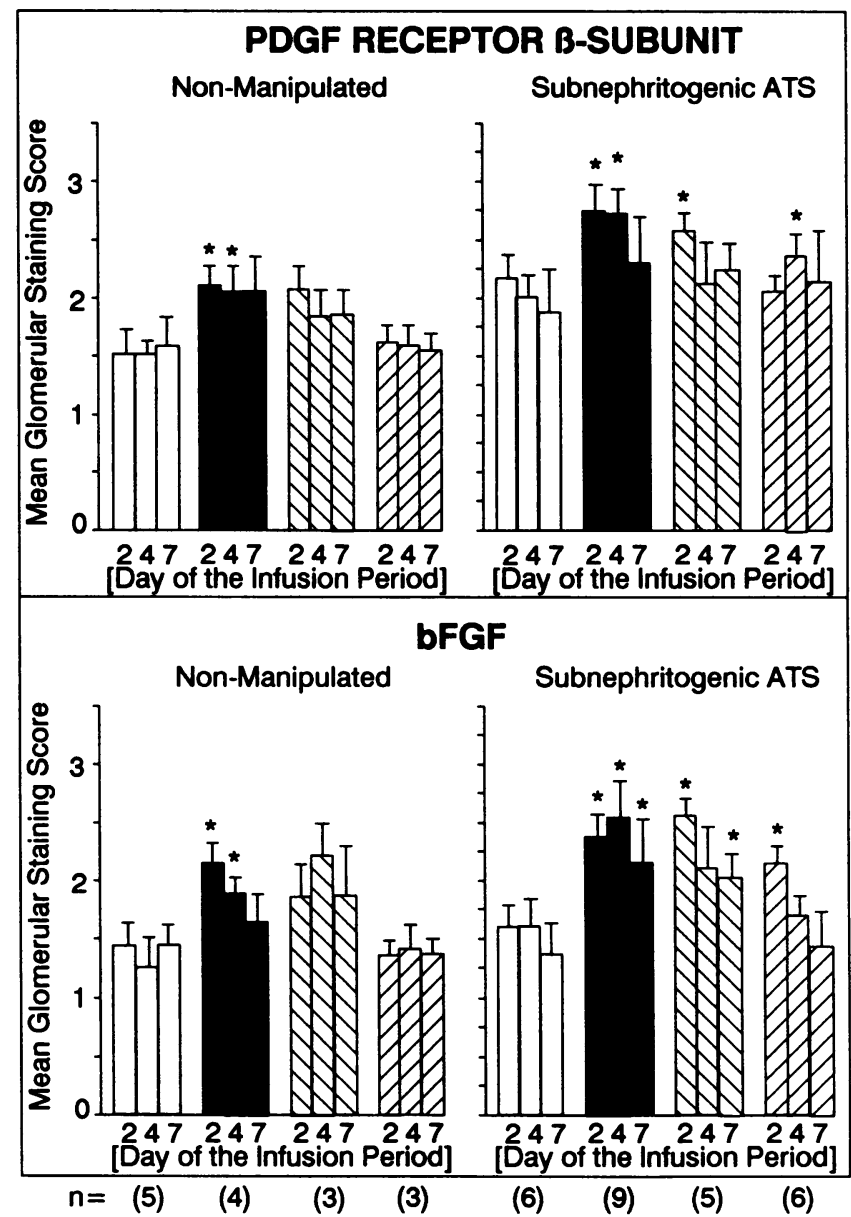

Figure 5. Glomerular growth factor expression: glomerular immunostaining scores for the expression of PDGF receptor $\beta$ subunit and bFGF in normal or subnephritogenic ATS rats receiving a 1-wk infusion of either PDGF-BB ( $₫)$, PDGF-BB plus bFGF ( $₫)$, bFGF ( $\square$ ), or vehicle $(\square) .{ }^{*} P<0.05$ vs corresponding vehicle-infused group. 
Table II. Glomerular mRNA Levels for PDGF Receptor $\beta$ Subunit in Normal Rats and Rats that Had Received a Subnephritogenic ATS Dose 2 d Previously

\begin{tabular}{lccccc}
\hline & \multicolumn{2}{c}{ Northern blot results } & & \multicolumn{2}{c}{ Dot blot results } \\
\cline { 2 - 3 } \cline { 5 - 6 } $\begin{array}{c}\text { Total glomerular } \\
\text { RNA obtained from }\end{array}$ & Absolute & $\begin{array}{c}\text { Percent } \\
\text { of normal }\end{array}$ & & Absolute & $\begin{array}{c}\text { Percent } \\
\text { of normal }\end{array}$ \\
\hline $\begin{array}{l}\text { Normal subjects } \\
\begin{array}{l}\text { Subnephritogenic } \\
\text { ATS, day 2 }\end{array}\end{array}$ & $2.55 \pm 0.05$ & - & $26.7 \pm 0.6$ & - \\
\hline
\end{tabular}

Results are expressed as absolute densitometric mRNA levels (see Methods) and mRNA levels relative to those observed in normal rats normalized for the expression of 28S rRNA (see Methods). Results are mean $\pm S D$ of three experiments each. Each experiment consisted of kidneys of two rats pooled to give a single RNA sample.

Effects of PDGF-BB and bFGF infusion on glomerular matrix synthesis and expansion. Silver methenamine staining of the extracellular matrix failed to reveal a significant change from the normal staining pattern in the biopsies obtained from normal rats infused with PDGF-BB and/or bFGF. In subnephritogenic ATS rats, there was a minor increase in mesangial silver staining on day 7 in the PDGF-BB-infused rats but not in those receiving bFGF or vehicle (Fig. 7).

Immunohistochemical staining patterns using the antibodies against types I and IV collagen, laminin, and fibronectin in normal rats have been reported previously (27), and were not different in the present study. Staining of the biopsies with the anti-type I collagen antibody did not reveal significant glomerular expression in any of the control or experimental groups (data not shown). In contrast, significant increases of the glomerular staining scores for type IV collagen, laminin, and fibronectin were noted in rats that had received a subnephritogenic ATS dose plus PDGF-BB or PDGF-BB + bFGF (Fig. 8). In all other groups, the changes observed were not statistically different from the findings in vehicle-infused rats (Fig. 8). Analysis of the glomerular expression of laminin $B_{2}$ chain mRNA on day 7 after the start of the infusion in subnephritogenic ATS

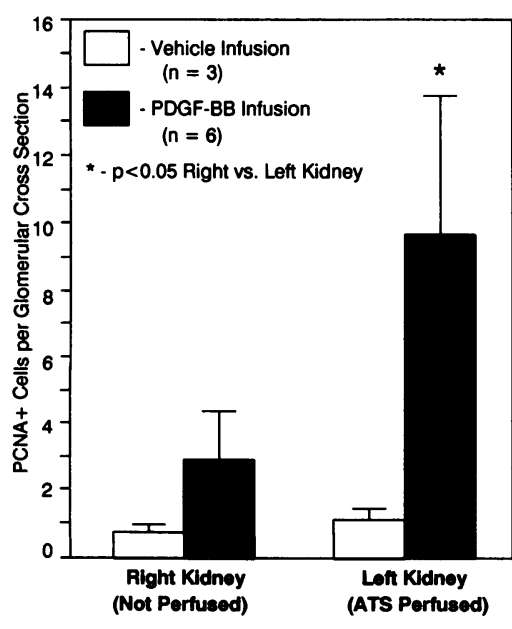

Figure 6. Glomerular cell proliferation after selective intrarenal deposition of ATS: proliferating cells per glomerular cross section (as defined by immunostaining for PCNA) at $48 \mathrm{~h}$ after the start of a PDGF-BB $(n=5)$ or vehicle $(n=3)$ infusion into rats that had received a subnephritogenic dose of ATS via renal artery perfusion into the left kidney only with drainage of the left renal vein. It is apparent that PCNA counts are

significantly increased in the ATS-perfused left kidney in comparison to the nonperfused right kidney.
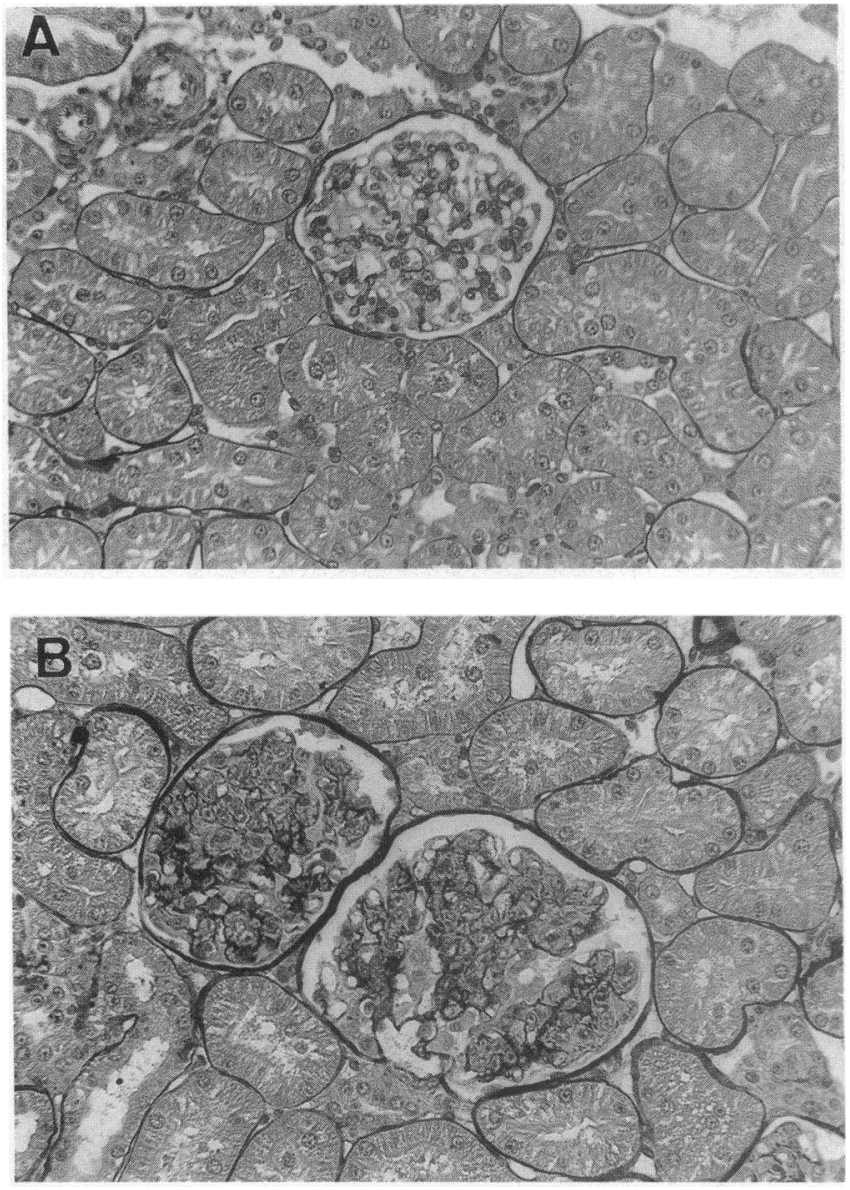

Figure 7. Glomerular matrix expansion: silver methenamine staining of renal biopsies of subnephritogenic ATS rats that had received a seven day infusion of either vehicle $(A)$ or PDGF-BB $(B)$. A minor increase in mesangial silver staining is observed in the PDGF-BB infused rat. $\times 400$

rats revealed a 4.8-fold increase in PDGF-BB-infused rats, but not in those receiving bFGF or PDGF-BB plus bFGF (Fig. 9). Glomerular expression of type IV collagen mRNA was also increased in PDGF-BB infused rats, as well as in those receiving bFGF, but not in those receiving the combination of both (Fig. 9) (relative increase over vehicle-infused rats: PDGF-BB, 2.8 \pm 0.6 -fold; PDGF-BB + bFGF, $1.5 \pm 0.6$-fold; bFGF, 2.5 \pm 1.1 -fold; all data corrected for the expression of $28 \mathrm{~S}$ RNA; $n=3$ each .

Effects of PDGF-BB and bFGF infusion on functional renal parameters. No significant proteinuria (normal: $<10 \mathrm{mg} / 24$ h) or increases in serum creatinine (normal: $40 \pm 4 \mu \mathrm{mol} /$ liter) or urea (normal: $8 \pm 0.8 \mathrm{mmol} /$ liter) developed in any of the groups (data not shown).

\section{Discussion}

The data presented in this study show that the administration of bFGF $\left(17 \mathrm{ng} / \mathrm{min}=10^{-12} \mathrm{M} / \mathrm{min}\right)$ and in particular of PDGF-BB (28 ng $/ \mathrm{min}=10^{-12} \mathrm{M} / \mathrm{min}$ ) can induce selective mesangial cell proliferation in the kidney, that this effect depends on the cellular status of the mesangial cell, that in cases of marked mesangial cell proliferation a concomittant overpro- 


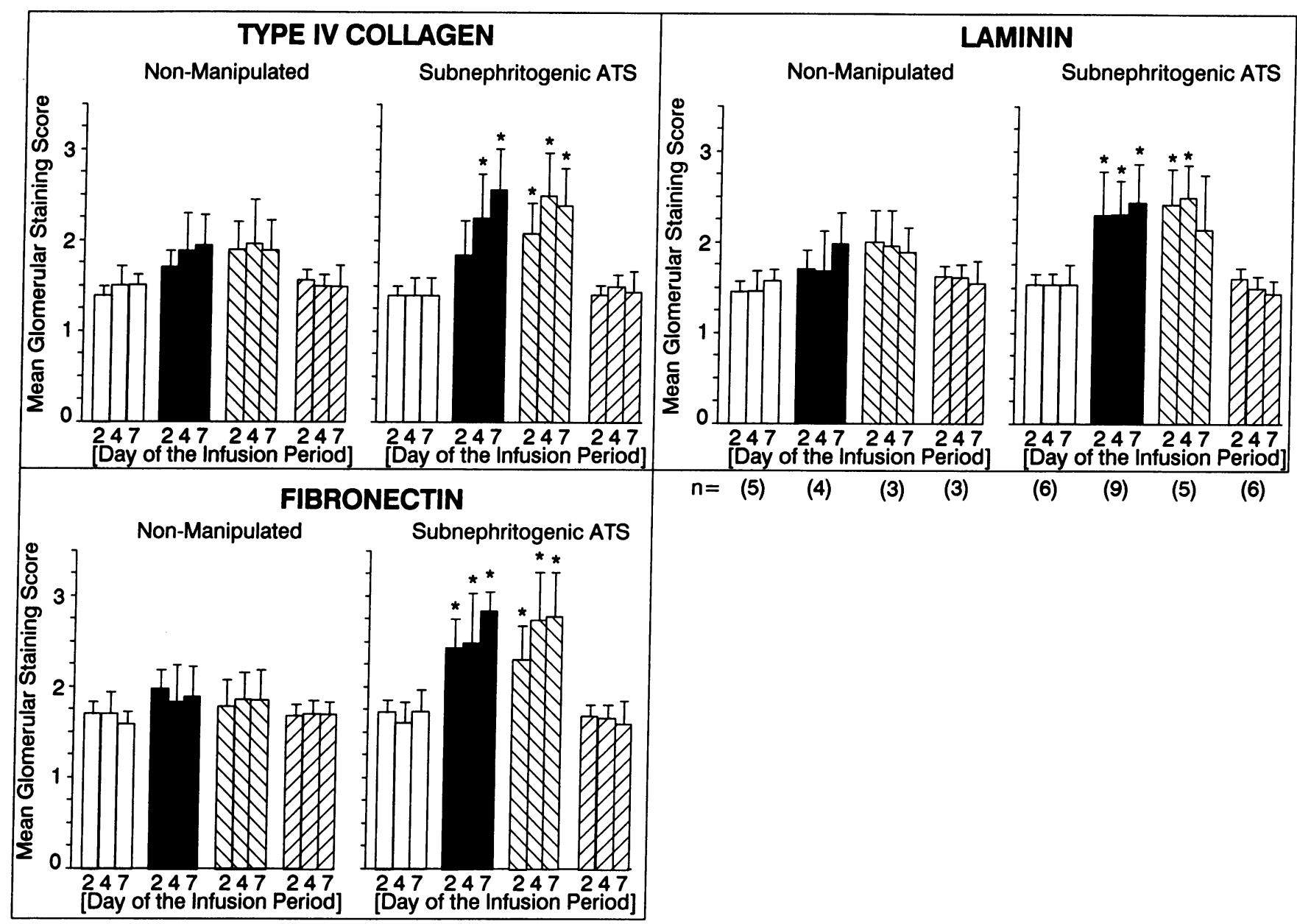

Figure 8. Glomerular immunostaining for matrix proteins: glomerular immunostaining scores for the expression of type IV collagen, laminin,

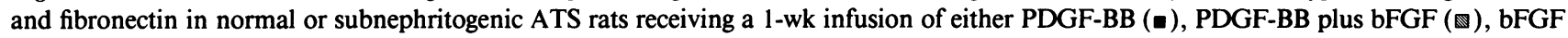
$(\square)$, or vehicle (ם). Increased immunostaining scores are confined to subnephritogenic ATS rats receiving PDGF-BB ( \pm bFGF) infusions. ${ }^{*} P$ $<0.05$ vs corresponding vehicle-infused group.

duction of extracellular matrix occurs, and that neither mesangial cell proliferation nor matrix accumulation are associated with a functional renal impairment during the short period of the study.

A main finding of this study was the selectivity of the induction of renal cell proliferation by PDGF and bFGF. Currently, no data exist on the renal cell types expressing receptors for bFGF in vivo. In vitro data, however, suggest that bFGF receptors are expressed by mesangial (10), glomerular endothelial (37), glomerular epithelial (38), and tubular epithelial cells (39), since it is mitogenic for these cell types. Immunohistochemical studies on the expression of PDGF receptor $\beta$ subunit in vivo have localized it to mesangial, parietal epithelial, and interstitial cells in human and primate kidneys (40). In cell culture, PDGF is mitogenic for cultured mesangial cells (7-9) and papillary interstitial fibroblasts (41). If bFGF and PDGF receptors are both expressed on a variety of renal cell types, what accounts for the selectivity of growth induction observed in the present study? In the case of bFGF, it is known from studies in vessels that only a previous injury renders cells, such as endothelial cells, responsive to the mitogenic effects of bFGF (42). These findings are consistent with our previous study (10) and with the present data, showing that only mesangial cells that had suffered a sublethal injury were growth responsive towards bFGF. Since the renal injury imposed by antiThy 1.1 antibody is specific for mesangial cells (15), this might be an explanation for the selectivity of bFGF-induced renal cell proliferation. In contrast to bFGF, PDGF-BB exerted mitogenic effects on mesangial cells in normal rat kidneys (although, again, mesangial injury increased the responsiveness). A concomittant increase in glomerular endothelial cell proliferation would not be expected since in normal human glomeruli no PDGF receptor $\beta$ subunit could be demonstrated on endothelial cells (40), and since bovine glomerular endothelial cells in vitro are nonresponsive towards PDGF (37). Glomerular epithelial cells, despite producing PDGF B chain (43), as well as proximal tubular epithelial cells in culture, have also been found to be nonresponsive to the mitogenic effect of PDGF $(43,44)$. The lack of detectable interstitial growth induction may have been a technical problem during the early phase of the infusion period, since only cortical biopsies were obtained. Cortical, in contrast to papillary, fibroblasts have been found to be relatively resistant to PDGF-induced proliferation (41). On the other hand, despite ongoing (though lesser) cell proliferation in glomeruli on day 7 of the PDGF infusion, no increased cell proliferation in the papillary tubulointerstitium was noted. 


\section{Type IV Collagen}

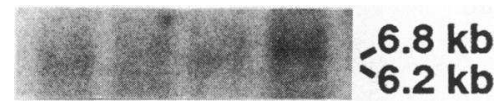

\section{Laminin B2 Chain}
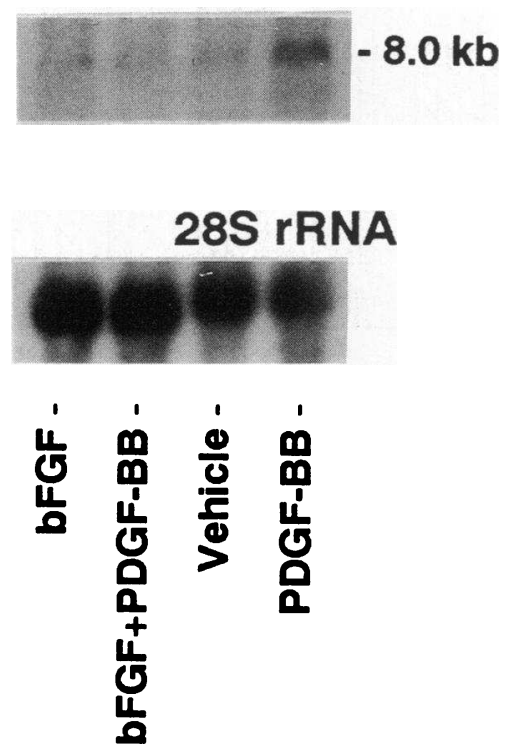

Figure 9. Glomerular type IV collagen and laminin $B_{2}$ chain mRNA expression: glomerular expression of mRNA for type IV collagen and laminin $B_{2}$ chain and 28S rRNA on day 7 after the start of the infusion of PDGF-BB, PDGF-BB plus bFGF, bFGF, or vehicle into subnephritogenic ATS rats. Increased type IV collagen mRNA expression is limited to PDGF-BBinfused and to bFGFinfused rats, while laminin $B_{2}$ chain mRNA expression is observed in the PDGF-BB-infused group only. One representative experiment is shown.

In the present study, PDGF-BB turned out to be a more potent mesangial cell mitogen in vivo than bFGF. In vitro data suggest that both cytokines exert mitogenic effects of a similar order of magnitude on mesangial cells $(8,45)$. However, these latter data were obtained in mesangial cells cultured under twodimensional conditions. Seeding of mesangial cells into a three-dimensional type I collagen matrix, in contrast, resulted in a complete loss of the mitogenic effect of PDGF (46). These controversial observations point to the problems associated with extrapolating from in vitro findings to the in vivo situation and underline the requirement for in vivo studies when evaluating the potential actions of cytokines during disease.

A second central finding of this study was the increased cytokine responsiveness of mesangial cells after minor degrees of immune-mediated injury. Since anti-Thy 1.1 antibody not only recognizes mesangial cells, but also thymocytes and various extrarenal cells (47), injection of the antibody might have led to release of substances from these latter cells that could have acted synergistically with the infused cytokines. However, this seems unlikely, since the increased responsiveness in anti-Thy 1.1 injected rats persisted when the antibody was deposited locally within one kidney and did not enter the systemic circulation. A second possibility is that the injected anti-Thy 1.1 antibody might induce glomerular leukocyte or platelet influx via increased release of chemoattractants or increases of the local procoagulant activity $(48,49)$. Both leukocytes and platelets contain potent mesangial cell growth factors $(1,4)$. Glomerular influx of inflammatory cells and increased thrombus formation induced by exogenously administered cytokines has been observed and may well be the explanation for findings in which the injection of interleukin-1 augmented glomerular hypercellularity in murine IgA nephropathy (50). In

contrast, neither a glomerular influx of leukocytes nor thrombus formation was observed in the present study. Our observations suggest a third mechanism, namely changes of the status of the intrinsic glomerular tissue to explain the increased cytokine responsiveness after minor injury. It is unclear whether the mild increase in glomerular PDGF receptor expression observed after the injection of subnephritogenic amounts of ATS can account for the increased cytokine responsiveness. Several other possibilities also merit consideration, namely ATS-induced post-receptor modulation or injury-related changes of the extracellular matrix that facilitate access of the infused cytokines to the cells. Finally, changes of glomerular cell apoptosis in the subnephritogenic ATS rats could contribute to alterations of the total glomerular cellularity.

Several findings of the present study suggest that the mitogenic effects of bFGF and PDGF-BB on mesangial cells in vivo were direct effects and not mediated via secondary mechanisms. No glomerular leukocyte or platelet influx, all of which contain potent mesangial cell mitogens $(1,4)$, or glomerular thrombus formation, with thrombin representing another potent mesangial cell mitogen (1), was observed in any of the groups. Furthermore, although not assessed by quantitative methods, we did not detect any apparent increase in the endogenous mesangial synthesis of PDGF B-chain. This latter finding contrasts with in vitro data showing that $10 \mathrm{ng} / \mathrm{ml}$ of bFGF or PDGF-BB markedly increased the synthesis of PDGF B-chain in mesangial cells ( 8 ). This discrepancy suggests that the local PDGF or bFGF concentrations achieved in our study may have been much lower than those used in the study of Silver et al. (8), and that the PDGF induced mesangial cell proliferation in our study resided in an exogenous rather than an autocrine effect. In contrast to PDGF B chain, glomerular immunostaining for bFGF increased in parallel to the induction of glomerular cell proliferation. Since this finding extended to both PDGF and bFGF infused rats, it did not appear to result from binding of infused bFGF to mesangial proteoglycans (10). More likely, the increase in glomerular bFGF immunostaining was the consequence of an increase in the number of mesangial cells, which, in contrast to PDGF $(22,28)$, constitutively express this cytokine in their cytoplasm (10). This increase in endogenous glomerular bFGF expression, however, is unlikely to mediate the augmented mesangial cell proliferation, since bFGF is not a secreted cytokine, but rather, is released after sublethal or lethal mesangial cell injury (10).

The last major finding of the present study was that the marked mesangial cell proliferation in vivo induced by PDGF$\mathrm{BB}$ was associated with a moderate overproduction and accumulation of extracellular matrix, supporting the concept that cell proliferation and matrix overproduction frequently are coupled events $(1,27,28)$. In agreement with our in vivo findings, cell culture data have shown that PDGF increases the mesangial cell synthesis of fibronectin, laminin, type IV collagen, and heparan sulfate proteoglycan (11). The observation that PDGF-BB infused rats had an increase in glomerular laminin $B_{2}$ chain and type IV collagen mRNA suggests that the accumulation of mesangial extracellular matrix was, in part, caused by upregulated synthesis. While the absence of increased laminin $B_{2}$ chain mRNA in bFGF-infused rats may relate to the lower degree of cell proliferation, this cannot explain the absence of an increase of both laminin $B_{2}$ chain and type IV collagen mRNA in rats infused with PDGF-BB plus bFGF, since mesangial cell proliferation in this group was as 
pronounced as in rats infused with PDGF-BB only. One possible explanation is that the concomitant infusion of PDGF-BB and $b F G F$ led to a more transient increase of glomerular lami$\operatorname{nin} B_{2}$ chain and type IV collagen mRNA expression. We may have missed this, since we could only obtain RNA on day 7 of the infusion period. Future experiments will have to clarify this point.

Interestingly, the increase in extracellular matrix components in PDGF-BB- and bFGF-infused rats was limited to components of the normal mesangial matrix. Neither interstitial (type I) collagen nor the expression of $\alpha$-smooth muscle actin was induced, despite being present in several models of glomerular diseases involving mesangial cell proliferation $(15,28)$. This suggests that mesangial cell proliferation and matrix expansion can occur without the mesangial cell acquiring phenotypic characteristics of "myofibroblasts" (51), and that other stimuli may be necessary (e.g., hemodynamic alterations or other cytokines) to induce these changes.

In conclusion, this study provides further evidence that PDGF and (to a lesser degree) bFGF may be involved in the increased mesangial cell proliferation and matrix expansion that occurs in a variety of glomerular diseases. Our findings also show that sublethal injury to glomeruli that has no, or only minimal, morphological correlates may induce glomerular changes of a yet undefined nature, that render the cells more responsive to the action of inflammatory mediators. From a clinical point of view, this might explain how a minor renal insult could have pronounced effects in the presence of a subclinical but ongoing autoimmune process. Finally, this study provides a further rationale to examine the effects of PDGF or bFGF antagonists on the course of progressive glomerular disease. However, as discussed elsewhere in more detail (5), before such interventional trials are undertaken, more insight into the question will have to be gained of when and how the physiological, (e.g., regenerative) role of cytokines becomes a pathological one.

\section{Acknowledgments}

The authors gratefully acknowledge the generous supply of PDGF-BB by C. Hart (Zymogenetics, Seattle, WA) and of bFGF by R. Eure (Synergen, Boulder, CO). The help of Katherine Gordon, Monika Kregeler, and Heike Claus in performing the experiments is also gratefully acknowledged.

This study was supported by U.S. Public Health Service grants DK43422, DK-34198, DK-07467, DK-40802, GM-35501, HL-47151, HL-42270, a grant from the Northwest Kidney Foundation, and by a postdoctoral stipend of the Deutsche Forschungsgemeinschaft to $\mathrm{J}$. Floege.

\section{References}

1. Striker, L. J., E. P. Peten, S. J. Elliot, T. Doi, and G. E. Striker. 1991. Mesangial cell turnover: effect of heparin and peptide growth factors. Lab. Invest. 64:446-456.

2. Alpers, C. E., K. L. Hudkins, A. M. Gown, and R. J. Johnson. 1992. Enhanced expression of "muscle-specific" actin in glomerulonephritis. Kidney Int. 41:1134-1142.

3. Klahr, S., G. Schreiner, and I. Ichikawa. 1988. The progression of renal disease. N. Engl. J. Med. 318:1657-1666.

4. Floege, J., E. Eng, B. A. Young, and R. J. Johnson. 1993. Factors involved in the regulation of glomerular mesangial cell proliferation in vitro and in vivo. Kidney Int. 43:S47-S54.

5. Johnson, R. J., J. Floege, W. G. Couser, and C. E. Alpers. 1993. Role of platelet-derived growth factor in glomerular disease. J. Am. Soc. Nephrol. 4:119128.
6. Abboud, H. E. 1993. Nephrology forum: growth factors in glomerulonephritis. Kidney Int. 43:252-267.

7. Shultz, P. J., P. E. DiCorleto, B. J. Silver, and H. E. Abboud. 1988. Mesangial cells express PDGF mRNAs and proliferate in response to PDGF. Am. J. Physiol. 255:F674-F679.

8. Silver, B. J., F. E. Jaffer, and H. E. Abboud. 1988. Platelet-derived growth factor synthesis in mesangial cells: induction by multiple peptide mitogens. Proc. Natl. Acad. Sci. USA. 86:1056-1060.

9. Floege, J., N. Topley, J. Hoppe, T. B. Barrett, and K. Resch. 1991. Mitogenic effect of platelet-derived growth factor in human glomerular mesangial cells: Modulation and/or suppression by inflammatory cytokines. Clin. Exp. Immunol. 86:334-341.

10. Floege, J., E. Eng, V. Lindner, B. A. Young, M. A. Reidy, and R. J. Johnson. 1992. Rat glomerular mesangial cells synthesize basic FGF. Release, upregulated synthesis and mitogenicity in mesangial proliferative glomerulonephritis. J. Clin. Invest. 90:2362-2369.

11. Doi, T., H. Vlassara, M. Kirstein, Y. Yamada, G. E. Striker, and L. J. Striker. 1992. Receptor-specific increase in extracellular matrix production in mouse mesangial cells by advanced glycosilation end products is mediated via platelet-derived growth factor. Proc. Natl. Acad. Sci. USA. 89:2873-2877.

12. Johnson, R. J., E. Raines, J. Floege, A. Yoshimura, P. Pritzl, C. E. Alpers, and R. Ross. 1992. Inhibition of mesangial cell proliferation and matrix expansion in glomerulonephritis in the rat by antibody to platelet derived growth factor. J. Exp. Med. 175:1413-1416.

13. Johnson, R. J., R. L. Garcia, P. Pritzl, and C. E. Alpers. 1990. Platelets mediate glomerular cell proliferation in immune complex nephritis induced by anti-mesangial cell antibodies in the rat. Am. J. Pathol. 136:369-374.

14. Yamamoto, T., K. Yamamoto, K. Kawasaki, E. Yaoita, F. Shimizu, and I. Kihara. 1986. Immunoelectron microscopic demonstration of Thy-1 antigen on the surface of mesangial cells in the rat glomerulus. Nephron. 43:293-298.

15. Johnson, R. J., H. lida, C. E. Alpers, M. W. Majesky, S. M. Schwartz, P. Pritzl, K. Gordon, and A. M. Gown. 1991. Expression of smooth muscle cell phenotype by rat mesangial cells in immune complex nephritis. J. Clin. Invest. 87:847-858.

16. Johnson, R. J., S. J. Klebanoff, R. F. Ochi, S. Adler, P. Baker, L. Sparks, and W. G. Couser. 1987. Participation of the myeloperoxidase- $\mathrm{H}_{2} \mathrm{O}_{2}$-halide system in immune complex nephritis. Kidney Int. 32:342-349.

17. Kurki, P., M. Vanderlaan, F. Dolbeare, J. Gray, and E. M. Tan. 1986 Expression of proliferating cell nuclear antigen (PCNA)/cyclin during the cell cycle. Exp. Cell Res. 166:209-219.

18. Skalli, O., P. Ropraz, A. Trzeciak, G. Benzonana, D. Gillessen, and G. Gabbiani. 1986. A monoclonal antibody against $\alpha$-smooth muscle actin: a new probe for smooth muscle differentiation. J. Cell Biol. 103:2787-2796.

19. Dijkstra, C. D., E. A. Dopp, P. Joling, and G. Kraal. 1985. The heterogeneity of mononuclear phagocytes in lymphoid organs: distinct macrophage populations in the rat recognized by monoclonal antibodies ED1, ED2, and ED3. Immunology. 54:589-599.

20. Sekiya, S., S. Gotoh, T. Yamashita, T. Watanabe, S. Saitoh, and F. Sendo. 1989. Selective depletion of rat neutrophils by in vivo administration of a monoclonal antibody. J. Leukocyte Biol. 46:96-102.

21. Shiraishi, T., S. Morimoto, K. Itoh, H. Sato, K. Sugihara, T. Onishi, and T. Ogihara. 1989. Radioimmunoassay of human platelet-derived growth factor using monoclonal antibodies toward a synthetic 73-97 fragment of its B-chain. Clin. Chim. Acta. 184:65-74.

22. Iida, H., R. Seifert, C. E. Alpers, R. G. K. Gronwald, P. E. Phillips, P. Pritzl, K. Gordon, A. M. Gown, R. Ross, D. F. Bowen-Pope, and R. J. Johnson. 1991. Platelet-derived growth factor (PDGF) and PDGF receptor are induced in mesangial proliferative nephritis in the rat. Proc. Natl. Acad. Sci. USA. 88:65606564.

23. Reilly, T. M., D. S. Taylor, W. F. Herblin, M. J. Thoolen, A. T. Chiu, D. W. Watson, and P. B. M. W. M. Timmermans. 1989. Monoclonal antibodies directed against basic fibroblast growth factor which inhibit its biological activity in vitro and in vivo. Biochem. Biophys. Res. Commun. 2:736-743.

24. Fouser, L., L. Iruele-Arispe, P. Bornstein, and E. H. Sage. 1991. Transcriptional activity of the $\alpha_{1}(I)$-collagen promoter is correlated with the formation of capillary-like structures by endothelial cells in vitro. J. Biol. Chem. 266:1834518351.

25. Bieber, F. 1985. Biotinylierung monoklonaler Antikörper. In Monoklonale Antikörper. Herstellung und Charakterisierung. Peters H. Berlin, editor. Springer pp. 209-212.

26. Bagchus, W. M., M. F. Jeunink, J. Rozing, and J. D. Elema. 1989. A monoclonal antibody against rat platelets. I. Tissue distribution in vitro and in vivo. Clin. Exp. Immunol. 75:317-323.

27. Floege, J., R. J. Johnson, K. Gordon, H. Iida, P. Pritzl, A. Yoshimura, C. Campbell, C. E. Alpers, and W. G. Couser. 1991. Increased synthesis of extracellular matrix in mesangial proliferative nephritis. Kidney Int. 40:477-488.

28. Floege, J., M. W. Burns, C. E. Alpers, A. Yoshimura, P. Pritzl, K. Gordon, R. A. Seifert, D. F. Bowen-Pope, W. G. Couser, and R. J. Johnson. 1992. Glomerular cell proliferation and PDGF expression precedes glomerulosclerosis in the remnant kidney model. Kidney Int. 41:297-309. 
29. Yoshimura, A., K. Gordon, C. E. Alpers, J. Floege, P. Pritzl, R. Ross, W. G. Couser, D. F. Bowen-Pope, and R. J. Johnson. 1991. Demonstration of PDGF B-chain mRNA in glomeruli in mesangial proliferative nephritis by in situ Hybridization. Kidney Int. 40:470-476.

30. Chomczynski, P., and N. Sacchi. 1987. Single-step method of RNA isolation by acid guanidinium thiocyanate-phenol-chloroform extraction. Anal. Bio chem. 162:156-159.

31. Yarden, Y., J. A. Escobedo, W. J. Kuang, T. L. Yang-Feng, T. O. Daniel, P. M. Tremble, E. Y. Chen, M. E. Ando, R. N. Harkins, U. and Francke, et al 1986. Structure of the receptor of platelet derived growth factor helps define family of closely related growth factor receptors. Nature (Lond.). 323:226-232.

32. Sasaki, M., and Y. Yamada. 1987. The laminin $B_{2}$ chain has a multidomain structure homologous to the B1 chain. J. Biol. Chem. 262:17111-17117.

33. Iruela-Arispe, M. L., C. A. Diglio, and E. H. Sage. 1991. Proteins by endothelial cells undergoing angiogenesis in vitro. Artherioscler. Thromb. 21:805-815.

34. Bradley, G. M., and E. S. Benson. 1974. Examination of the urine. In Todd-Sanford Clinical Diagnosis by Laboratory Methods. I. Davidson and J. B. Henry, editors. W. B. Saunders Company, Philadelphia, PA. pp. 74-80.

35. Wallenstein, S., C. L. Zucker, and J. L. Fleiss. 1980. Some statistical methods useful in circulation research. Circ. Res. 47:1-9.

36. Pabst, R., and R. B. Sterzel. 1983. Cell renewal of glomerular cell types in normal rats. An autoradiographic study. Kidney Int. 24:626-631.

37. Ballermann, B. J. 1989. Regulation of bovine glomerular endothelial cell growth in vitro. Am. J. Physiol. 256:C182-C189.

38. Takeuchi, A., N. Yoshizawa, M. Yamamoto, Y. Sawasaki, T. Oda, A. Senoo, H. Niwa, and Y. Fuse. 1992. Basic fibroblast growth factor promotes proliferation of rat glomerular visceral epithelial cells in vitro. Am. J. Pathol. 141:107-116.

39. Zhang, G., T. Ichimura, A. Wallin, K. Mikio, and J. L. Stevens. 1991. Regulation of rat proximal tubule epithelial cell growth by fibroblast growth factors, insulin-like growth factor- 1 and transforming growth factor-a, and analysis of fibroblast growth factors in rat kidney. J. Cell. Physiol. 148:295-305.

40. Alpers, C. E., R. A. Seifert, K. L. Hudkins, R. J. Johnson, and D. F.
Bowen-Pope. 1993. PDGF-receptor localizes to mesangial, parietal epithelial, and interstitial cells in human and primate kidneys. Kidney Int. 43:286-294.

41. Knecht, A., L. G. Fine, K. S. Kleinman, P. Rodemann, G. A. Miller, D. D. L. Woo, and J. T. Norman. 1991. Fibroblasts of rabbit kidney in culture II. Paracrine stimulation of papillary fibroblasts by. PDGF. Am. J. Physiol. 261:F292-F299.

42. Lindner, V., R. A. Majack, and M. A. Reidy. 1991. Basic fibroblast growth factors mediates endothelial regrowth and proliferation in denuded arteries. $J$. Clin. Invest. 85:2004-2008.

43. Floege, J., R. J. Johnson, C. E. Alpers, C. A. Richardson, K. Gordon, and W. G. Couser. 1993. Visceral glomerular epithelial cells can proliferate in vivo and synthesize PDGF B-chain. Am. J. Pathol. 142:637-650.

44. Humes, H. D., T. F. Beals, D. A. Cieslinski, I. O. Sanchez, and T. P. Page 1991. Effects of transforming growth factor- $\beta$, transforming growth factor- $\alpha$, and other growth factors on renal proximal tubule cells. Lab. Invest. 64:538-545.

45. Issandou, M., and J. M. Darbon. 1991. Basic fibroblast growth factor stimulates glomerular mesangial cell proliferation through a protein kinase $\mathrm{C}$-independent pathway. Growth Factors. 5:255-264.

46. Madri, J. A., and M. Marx. 1992. Matrix composition, organization, and soluble factors: modulators of microvascular cell differentiation in vitro. Kidney Int. 41:560-565.

47. Barclay, A. N. 1981. Different reticular elements in rat lymphoid tissue identified by localization of Ia, Thy- 1 and MRC OX 2 antigens. Immunology. 44:727-736.

48. Bagchus, W. M., M. F. Jeunink, and J. D. Elema. 1990. The mesangium in anti-Thy-1 nephritis. Am. J. Pathol. 137:215-222.

49. Poelstra, K., M. J. Hardonk, J. Koudstaal, and W. W. Bakker. 1990. Intraglomerular platelet aggregation and experimental glomerulonephritis. Kidney Int. 37:1500-1508.

50. Montinaro, V., K. Hevey, L. Aventaggiato, K. Fadden, A. Esparza, A Chen, D. S. Finbloom, and A. Rifai. 1992. Extrarenal cytokines modulate the glomerular response to IgA immune complexes. Kidney Int. 42:341-353.

51. Johnson, R. J., J. Floege, A. Yoshimura, H. lida, W. G. Couser, and C. E. Alpers. 1992. The activated mesangial cell: A glomerular "myofibroblast"? $J$. Am. Soc. Nephrol. 2:S190-S197. 